が認められ, $\mathrm{SiO}_{2}$, 含量の高いガラスほどその生成量も 大である。また，珪砂の熔融過程でフシを生成すること が確認された。これらのことからフシ㳊揮発によるもの でもなく，また分相に基ら゙くものでもないことが明らか である、このようにして生じるフシの屈折率は低い. た, 表-1 に見られたよらに屈折率の高いつシも極く僅 かで注るが存在するため稀には耐火物からの石によ。 ても生じると考えられる。

次に難溶性原料である珪砂は熔融不十分により塊状の

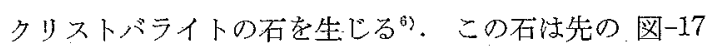
に見られるように熔融時間の延長と共に消失する，その 周囲のガラスの 屈折率は低い. また $\mathrm{Na}_{2} \mathrm{O}, \mathrm{B}_{2} \mathrm{O}_{3}$ の揮発. によって生じた極めて $\mathrm{SiO}_{2}$ に富む表面層から薄膜状の クリストバライトが晶出して石になる早,?).

而火物の小片が熔融ガラス中に混入した場合にも石を 生じる.この耐火物からの石の熔解により IV.1.iii.の 項で述べたように，その周囲のガラスの屈折率は低、も のも高いものも共に存在する.

\section{VI. 結論}

以上得られた結果から，先の表-1 で実際のパイレッ クスガラス容器中に存在する脈理, フシ, 石について屈 折率変化より示された結果は次のように結論することが 出来了.

(i) 脈理 低屈折の脈理 $(34.9 \%)$ が多いがこれは 熔融初期では難溶性原料である $\mathrm{SiO}_{2}$ によって生じ，長 時間経過したところでは表面揮発によって生じたもので ある. 高屈折の脈理 (17.4\%) は耐火物の侵蝕によって
生じた $\mathrm{Al}_{2} \mathrm{O}_{3}, \mathrm{ZrO}_{2}$ によるもので低屈折の脈理に此 て少ない。また，スタグナントは耐火物の侵蝕による のであり高屈折の脈理を生じる.

(ii) フシ フシは分相によるものではない，大埆 分のものは低屈折(24.6\%)でかつ熔融時間が長くなると 減少する事から，表湎揮発分主な原因でなく主として曐 溶性 $\mathrm{SiO}_{2}$ によるものである.また, 高屈折のフシ (1.1 \%) も極めて僅汃で注亦るが存在し，これ耐火物加ら の石の熔解過程において生じると考えられる.

(iii) 石石の原因として耐火物の侵蝕, 未溶融の $\mathrm{SiO}_{2}$, 表面失透が考えられるが，フシの場合と同様に大 部分の石は原料珪砂の未熔解によるもので石の周囲の分 ラスの屈折率泜低、(14.6\%). 高屈折のガラスに囲虫 れる石 $(3.7 \%)$ は耐火物によるものである。

\section{文献}

1) J.C. Turnbull, L.G. Ghering, J. Am. Ceram. Soc., 24 [8] 264-70 (1941).

2) R.L. Tiede, F.V. Tooley, J. Am.Ceram. Soc., 27 [2] 42-45 (1944).

3) R.L. Tiede, F.V. Tooley, J. Am. Ceram. Soc., 28 [2] $42-47$ (1945).

4) M.A. Knight, Glass Ind., 37 [10] 553 (1956).

5) L.F. Oldfield, R.D. Wright, Advances in Glass Technology (VI International Congress on Glass) (1962).

6) R. Katzschman, Silikattechn., 13 [3] 96-101 (1962).

7) L.F. Oldfield, R.D. Wright, Glass Tech., 3 [2] 5968 (1962).

8) G.E. Rindone; D.E. Day, J.Am. Ceram. Soc., 45 [10] 489-504 (1962); ibid., 45 [12] 579-81 (1962).

$(6 / 25 / 65$ 受付)

\title{
ガラス化範囲と冷却速度
}

\section{今岡稔・蔵方宏之・田井真一・野々宮弘 \\ (東京大学生产技術研究所)}

\section{Glass-formation Range and Cooling Rate}

By

\author{
Minoru IMAOKA, Hiroyuki KURAKATA, Shinichi TAI \\ and Hiroshi NONOYAMA \\ (Institute of Industrial Science, University of Tokyo, Tokyo)
}

\begin{abstract}
We have already studied the condition of glass-formation and the glass-formation range of borates, silicates and germanates. In these studies, however, we could not determine precisely the cooling condition which defines the glass-formation range, because the glassy stateis not a stable state, but a sub-stable one. These experiments were made under conditions which were determined for the sake of experimental convenience : namely, 1/80 mols of specimen were melted and cooled naturally in a room. Therefore, it is necessary to examine to what extent the results of these experiments are effective in view of the glass structure. In this study experiments were carried out by changing the cooling rate,
\end{abstract}


and the variation in the glass-formation range with various cooling rates was examined. These cooling processes included the followings : quick cooling by water, natural cooling in a room (cf. Curve I in Fig. 1), natural cooling in a furnace (cf. Curve II in Fig. 2) and slow cooling in a furnace controlled by a thermocontroller. These cooling rates are about $3 \times 10^{2}, 10,1.5 \times 10^{-1}$ and $1.2 \times 10^{-30} \mathrm{C} / \mathrm{sec}$, respectively. The amount of molten glass is the same as that in the previous studies; crucibles employed are made of platinum or its alloy, which may have some effect especially in the case of the slow cooling in a furnace.

Ternary borate systems have been chosen as the glass-forming system for the convenience of experiment, which have been divided into common systems and exceptional systems. The former include the B-type ternary system as the containing only the oxides of the a-group elements, the $\mathrm{PbO}$-containing ternary system as the one containing both of the oxides of the a-group and the b-group elements, and the $\mathrm{B}_{2} \mathrm{O}_{3}-\mathrm{Bi}_{2} \mathrm{O}_{3}-\mathrm{PbO}$ system as the one containing only the oxides of the b-group elements. The results are shown in Fig. 1-19. These glass-formation ranges contain various critical lines of vitrification; the limit of the continuity of a network-structure (the AD-line in Fig.2 and 3), the existing limit of necessary modifier ions for the network-formation (the $\mathrm{B}_{2} \mathrm{O}_{3}-\mathrm{C}$ line in Fig. 2 and 3 ), and the exchangeable limit of network ions represented by the number of b-group ions connecting $B$ with $B$ in the network-structure (the $A_{1} B_{2}, A_{2} B_{3}, \cdots$ lines in Fig. 8; cf. Table 1). The glass-formation range expressed by the above critical lines generally varies somewhat according to the variation in the cooling rate. Therefore the result of the glass-formation range under an arbitrary cooling condition has no absolute meaning. However, comparing Fig. 4 with Fig. 5, for example, we can see a similar variation in the glass-formation range in both cases. In the one case the modifier ions are not exchanged but the cooling conditions are changed, while in the other the modifier ions are exchanged but the cooling conditions are kept constant. This fact can be explained by assuming the 3-dimensional glass-formation range including the glass stability as shown in Fig. 7. When the modifier ion in the $\mathrm{B}_{2} \mathrm{O}_{3}-\mathrm{PbO}-\mathrm{RO}$ system (Fig. 5) is smaller, so that its vitrified system is more unstable, the glass-formation occurs only in the high stability sections. The case is the same when the cooling rate is slower in a more stable vitrified system.

We then studied the $\mathrm{B}_{2} \mathrm{O}_{3}-\mathrm{MgO}-\mathrm{BaO}$ system (Fig. 9), the $\mathrm{B}_{2} \mathrm{O}_{3}-\mathrm{TiO}_{2}-\mathrm{BaO}$ system (Fig. 12), the $\mathrm{B}_{2} \mathrm{O}_{3}-\mathrm{WO}_{3}-\mathrm{Li}_{2} \mathrm{O}$ system (Fig. 15) and the $\mathrm{B}_{2} \mathrm{O}_{3}-\mathrm{K}_{2} \mathrm{O}-\mathrm{Bi}_{2} \mathrm{O}_{3}$ system (Fig. 17) as exceptional ternary systems and discussed the true feature of the anomaly of these systems. In the $\mathrm{B}_{2} \mathrm{O}_{3}-\mathrm{MgO}-\mathrm{BaO}$ system, for example, the glass-formation range by natural cooling (Curve 2 in Fig. 9) overruns the hatched parts. The glass-formation range by natural cooling in a furnace (Curve 3 in Fig. 10), however, resembles that of the $\mathrm{B}_{2} \mathrm{O}_{3}$ $\mathrm{MgO}-\mathrm{K}_{2} \mathrm{O}$ system, no more exhibiting the anomaly. On the other hand, in the $\mathrm{B}_{2} \mathrm{O}_{3}-\mathrm{MgO}-$ $\mathrm{K}_{2} \mathrm{O}$ system, the glass-formation range by quick cooling by water (Curve 1 in Fig. 10) resembles that of the $\mathrm{B}_{2} \mathrm{O}_{3}-\mathrm{MgO}-\mathrm{BaO}$ system. The other examples(Fig. 11-19)also give almost the same result, and variations with the cooling rate resemble variations with the ion exchange as in the above-mentioned examples. From theser esults, we can say that the glassformation range under a cooling condition has only a relative meaning. We can also say. that the glass-formation range of a system is 3-dimensional one containing the stability of the glassy. state as an additional factor, as shown in Fig. 7. Therefore, previous 2-dimensional glass-formation ranges and critical lines must be considered in these 3-dimensional glass-formation ranges. In addition to these glass-formation ranges, there are sometimes unstable glassy states which widen their glass-formation ranges under the condition of quick cooling (for example, Curve 2 in Fig. 12.).

We also studied the relation between the glass-formation range and the equilibrium diagram of the system (cf. Fig. 20-22). Assuming that the variation in the viscosity of molten glasses with their compositions is not very large, we can say that the vitrification is difficult at the top of the liquidus line, while easy in the valley. In fact we can observe vitrification at about 30 mole $\%$ of $\mathrm{B}_{2} \mathrm{O}_{3}$ (in Fig. 21) and crystalization at about 80 mole\% of $\mathrm{B}_{2} \mathrm{O}_{3}$ (in Fig. 20); these results agree with the above theory. In Fig. 20-23 however, the glass-formation range does not always correspond to the height of the-liquidus line. This means that the appearance of the vitrified state or the crystalline state is affected by the structure of the molten state (the temperature of which may be higher than the melting point or the liquidus temperature). This consideration corresponds to the previous view of the condition of glass-formation from the view point of the formation of network- 
structure. About the critical region where the glassy state becomes unstable, however, the transformation from the sub-stable glassy state to the stable crystalline state depends mainly on the viscosity. In these cases the glass-formation range is influenced by the equilibrium diagram.

[Received July 12, 1965]

\section{I.はしがき}

著者らはこれまで「ガラス化条件について」注か，硼

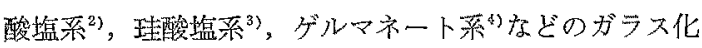
範囲について本誌に発表し，その他ガラス化範囲の問題 を現在な驺いるいる取报って来ている・ところでこれら の一連の研究に㧍いて，功ラス化範囲を決める実験条件 は，総量 $1 / 80 \mathrm{~mol}$ を熔融し，その後空内で放冷してガ ラスかどらかを調べるというものでここれは全く害験上 の都合で決められたものである。ガラス化範囲を調べて いる他の研究では, $100 \mathrm{~g}, 50 \mathrm{~g}$ といった規模のものや,

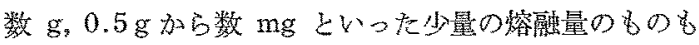
あり，一般には室内で放洽されているが，ドライアイス や液体空気の中に落して急冷しているものもあり，目的 による差もるるが標準条件といったものは存在しない。 結局ガラス状熊注安定状態で活なく, 準安定状態にすぎ ないことから起ることで，上記の現状注然としなけれ 壮ならないしかしそのことは「ガラス化範囲」の意味 を，単なる傎向を示した相刘的なものにしているわ斿で 㸚る。そこでこうした熔融量や泠却速度による変化も含 めた，ガラス化範囲の全貌といったもの索知る必要もあ り，それと同時に従来任意に決めた条件のもとで調べて 来たガラス化範围が，果して十分意味のあるものであ。 たかどうかここで検討して置く必要もあると考えられ 万.

ところでガラス化の問題を，分子の集合状態に関する 熱力学的問題として，理諭的纪解いていこうとする考光 方があり，さきに Rawson ${ }^{5)}$ む゙ラス化は状態図に捛け る液相線の谷閒に起るとして，ガラス化能力を測る尺度 として Single Bond Strength (単結合当りの生成熱) を，熔融点の絶対温度で割った值を提案しているが，必 ずしも実際と一致してはいないまた核生成速度や結晶

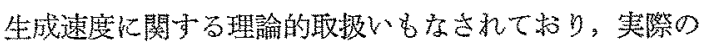
結晶化過程をある程度説明していることる事実で少る が，しかしそこで取披いらる範囲は，どこまでもある特 定な系の結晶化現象の問題であって，任意の系に数ける ガラス化範困のような組成的知識定求めることは, 理諭 的には可能であっても実際には出来ないことである。皇 れはさて招いても, 状態図に示された平衡状態に活りる

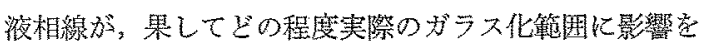
与えているが，興味方問題でるる。前記の冷却速度 の問題にあわせて，これらの関係もみていきたい。

\section{II. 实 験 方 法}

さてガラス化範囲を決汤る上の条件として冷却速度と
熔融量意上げたが，本質的に注泠却速度がガラス化範围 を左右する。しかし実際問題としては熔融畾の方が問題 になるし，また坩堝を使って熔しているので，熔融物が 坩城との接触面で結晶しや子いといったことも市りう る.とくに本実験の場合の上万に少量熔融の場合, 熔融 量に比して接触面積も大きく影響を受けやすいし，とく に冷却速度の遅い場合その影響が現かれや小い。その意 味では冷却速度を一定にして熔融量を変える方が実際的 であるが，実行の面で別の困難がある，そこで本実駰で は，熔融量は前記の $1 / 80 \mathrm{~mol}$ をそのまま変えずに，冷 却速度を急冷, 放冷, 炉内放泠, 炉内徐椧の 4 段階に変 えてガラス化範团を調べた。このうち放冷は従来の実験 条件で, 冷却速度㹥約 $10^{\circ} \mathrm{C} / \mathrm{sec}$. (図-1 参照) である. 急洽は熔融状態で坩堝をいきなり永水に浸けるるので, 泠却速度の寒測は困難であるが $3 \times 10^{2 \circ} \mathrm{C} / \mathrm{sec}$ 程度々推 定される。炉内放冷注 $1000^{\circ} \mathrm{C}$ に加熱された電気炉中 で，電源を切って放泠するもので，図-1 の曲線から結 晶化の温度域での泠却速度は的 $1.5 \times 10^{-1 \circ} \mathrm{C} / \mathrm{sec}$ で文 る. 最後の炉内徐椧注温度調節器を使って徐泠している もので，その速度は $25^{\circ} \mathrm{C} / \mathrm{hr}\left(7 \times 10^{-3 \circ} \mathrm{C} / \mathrm{sec}\right)$ である。

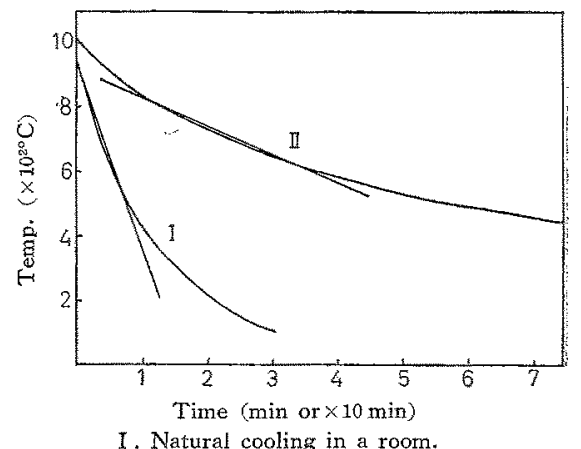

1. Natural cooling in a room.

II. Natural cooling in a furnace.

Fig. 1. Cooling velocity of molten glass.

これまでガラス化範园を調べた系（室内放冷）恃き めて多数に上り，その一つ一つについて冷却速度を変え た実験を絽返すことは容易ではなく，また必ずしもをの

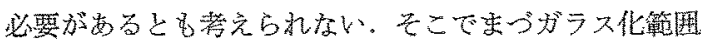
の代表的タイプを取上げ，それについて謂べることにし た。、族元素の酸化物系ではA 型, B 型㜿よびC型 3 成 分系に分けられるが，C型恔为ラス化範四が狭く、A型 は実筫的にB型の中に含まれると考えてよいので，B型 3成分系のみを取上げた。次にb族元素の酸化物を含さ 系では, $\mathrm{b}$ 族酸化物の典型として $\mathrm{Pb}$ を含む系を取上げ た. 以上の一般系の他にやや例外的なガラス化範国を持 つ䒺として, $\mathrm{B}_{2} \mathrm{O}_{3}-\mathrm{MgO}-\mathrm{BaO}$ 系, $\mathrm{B}_{2} \mathrm{O}_{3}-\mathrm{TiO}_{2}-\mathrm{BaO}$ 系， 
$\mathrm{B}_{2} \mathrm{O}_{3}-\mathrm{WO}_{3}-\mathrm{Li}_{2} \mathrm{O}$ 系, $\mathrm{B}_{2} \mathrm{O}_{3}-\mathrm{Bi}_{2} \mathrm{O}_{3}-\mathrm{K}_{2} \mathrm{O}$ 系など，またそ れの関連系を調べた。一般に嗍酸塩系について行なった が，これは熔融しやすいなどの実験上の便利からであ る. その他状態図との関係を検討する上で, $\mathrm{B}_{2} \mathrm{O}_{3}-\mathrm{Na}_{2} \mathrm{O}$ 系, $\mathrm{B}_{2} \mathrm{O}_{3}-\mathrm{PbO}$ 系など若干の 2 就よび 3 成分系につい ても調べた。

なお以上の実験に掠いて一番問題と思われるのは炉内 徐冷の場合で, 前記のように畦堝との接触面積が大きい とか，熔融時間が不十分で完全に均一でなかったとか， いろいろのガラス化を妨げる影響を受けや寸い。その他 白金などの金属坩堝を使用しているので，これらの金属 イオンがガラス中に微量にとけこんで，結晶化の核とな らないとは限らない，例えばラルライトガラスの場合な ど，金属坩堝を使らのとアルミナ坩堝とでは，ガラス化 範国の上に大きな差が現われるが，それはアルミナが熔 汀込んだことによる美よりも大きく，上記のような原因 も関係しているのではないかと想像される。また中には 急冷した場合にかえってそれが刺戟となって，失透する ような例もないことはない $\left(\mathrm{B}_{2} \mathrm{O}_{3}-\mathrm{Li}_{2} \mathrm{O}\right.$ 系など). した がって本実験の結果にも, 詳細に検討していけげさらに 訂正を要する個所がないとはいえない。しかし多数の実 験が絽返されているので，大局を変えるような大きな誤 りはないと確信している。

\section{III. 冷却速度によるガラス化範囲の変化}

\section{A. 一般的 3 成分系}

i. B 型 3 成分系 まづB型 3 成分系からみてゅく

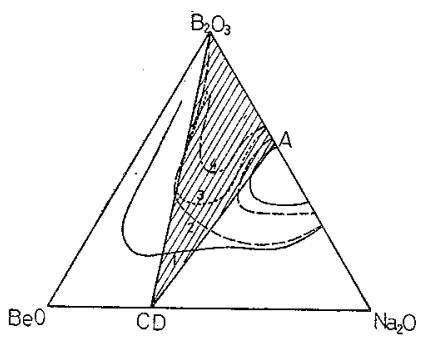

1. quick cooling,

2. natural cooling in a room

3. natural cooling in a furnace,

4. slow cooling in a furnace.

Fig. 2. Glass-formation range in $\mathrm{B}_{2} \mathrm{O}_{3}-\mathrm{BeO}-\mathrm{Na}_{2} \mathrm{O}$ system.

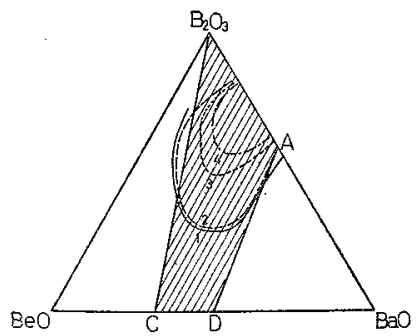

Fig. 3. Glass-formation range in $\mathrm{B}_{2} \mathrm{O}_{3}-\mathrm{BeO}-\mathrm{BaO}$ system.
ことにしたい。既 報 ${ }^{1)}$ 亿詳述されて いるよらにこの型 のガラス化範围は 3 〜 つの限界線によ って囲まれている。 第 1 は網状構造の連 続性の限界（図-2,3 の $\mathrm{AD}$ 線)である。 第 2 は網状構造化に 必要な修飾イオンの 存在限界(図-2,3 の $\mathrm{B}_{2} \mathrm{O}_{3}-\mathrm{C}$ 線)である。 第 3 柱網状構造成分 がガラス形成成分の 網状構造を置換し5 る置換限界で，これ いない、構造上から 生ずる限界線ではな いからである、第 4 は図中に恃されて
の不混領域の限界も同様で，これはアルカリ酸化物との 系のように全く存在しない場合もある。まゔ 図-2,3に 示したのは $\mathrm{B}_{2} \mathrm{O}_{3}-\mathrm{BeO}-\mathrm{Na}_{2} \mathrm{O}$ 系掠よび $\mathrm{B}_{2} \mathrm{O}_{3}-\mathrm{BeO}-\mathrm{BaO}$ 系である。実測した系汢この他にもいくつかあるが，そ れらの結果もほぼ大同小異であるので，それらの掲載は 省略した。ところで泠却速度が遅くなるにしたがってガ ラス化範囲は狭くなるが， $\mathrm{B}_{2} \mathrm{O}_{3}-\mathrm{BeO}-\mathrm{Na}_{2} \mathrm{O}$ 系では 1 (急冷) と 2 (室内放冷) のガラス化範围の差が目立ち， 一方 $\mathrm{B}_{2} \mathrm{O}_{3}-\mathrm{BeO}-\mathrm{BaO}$ 系では 1 と 2 の間に差がなく，蚂 しろ 2 と 3 (炉内放冷) のガラス化範国の差が目立つ。 したがって冷却速度とガラス化範囲の変化の間に一定し た関係は存在しない。また限界線 $\mathrm{AD}$ および $\mathrm{B}_{2} \mathrm{O}_{3}$-C 線 に対しても，はっきり特徵づけられるような傾向は見当 らない。ただ以上の 2 つの限界線の変化は, 網状構造の 置換限界の変化にくらべて明かに小さい。

さて，この研究でガラス化条件から導き出された限界 線 $\mathrm{AD}$ 線， $\mathrm{B}_{2} \mathrm{O}_{3}-\mathrm{C}$ 線などが，どの程度はっきり裹づけ られるかは第 1 の問題点であった。しかし以上の結果か らはそうした裏ゔけはなかったといってよい。ただ網状 構造の置換限界の変化にくらべては変化の幅は猜く， $\mathrm{B}_{2} \mathrm{O}_{3}-\mathrm{BeO}-\mathrm{Na}_{2} \mathrm{O}$ 系でも $2,3,4$ のガラス化範囲注 $\mathrm{B}_{2} \mathrm{O}_{3}$ 一C 線とかなり一致している。しかしこらした一致も傾 向であって絶対的なものではない。そしてこれがガラス 化といら準安定状態としての必然でもあるう。なお一言 ぶれておきたいことは， $\mathrm{B}_{2} \mathrm{O}_{3}-\mathrm{BeO}-\mathrm{Na}_{2} \mathrm{O}$ 系にみられる $\mathrm{B}_{2} \mathrm{O}_{3}-\mathrm{C}$ 線の左側のガラス化領域や，いわゆる $\mathrm{B}_{2} \mathrm{O}_{3}$ $\mathrm{Na}_{2} \mathrm{O}$ 系の離島を結ぶ $\mathrm{AD}$ 線の下側のガラス化部分は， ある冷却速度以下では全くなくなっていない，本来のガ ラス化範囲にくらべ安定度の低いことを示している。こ れらのガラス化はそれぞれの系の特殊性から起るむの で，一般論からは切離して考える必要があるら。

ii. $\mathbf{B}_{2} \mathbf{O}_{3}-\mathbf{B a O}-\mathbf{P b O}$ 系 次に a および b 族元素酸 化物を含む系の代表として，この $\mathrm{B}_{2} \mathrm{O}_{3}-\mathrm{BaO}-\mathrm{PbO}$ 系它 取上げた。b族元素における大きな特徴は, 陽イオンと して修飾成分であると同時に網状構造成分としても大り らる点で，その中でも $\mathrm{PbO}$ は代表的成分である。その 結果は 図-4 に示した。ここで気付くことは，この泠却 速度の変化によるガラス化範囲の変化が， $\mathrm{B}_{2} \mathrm{O}_{3}-\mathrm{RO}-$ $\mathrm{PbO}$ 系（図-5 に示した）に抬けるアルカリ土類酸化物 $\mathrm{RO}$ の置換 $(\mathrm{Ba} \rightarrow \mathrm{Sr} \rightarrow \mathrm{Ca} \rightarrow \mathrm{Mg})$ による変化に，よく似 ていることである。図中の $\mathrm{P}$ 点は 2 価 4 配位の $\mathrm{Pb}$ が 2 価の修飾イオン $\mathrm{Pb}$ によって網状構造化が起り，それと 本来の網状構造 $\mathrm{BO}_{3}$ が交互に存在しうる点である。 $\mathrm{Q}$ 点はB索取巻く 3 個の $\mathrm{Pb} 4$ 配位のうち,2個の $\mathrm{Pb}$ が 網状構造化に必要な 2 価の修飾イオンとして, $\mathrm{Pb} の$ 代 りにアルカリ類イオンをとったと考えられる点であ り，さらにR点壮 $\mathrm{B}$ の配位の1つを修飾イオンに置換え た点で, 網状構造の連続性の限界である。この際イオン 


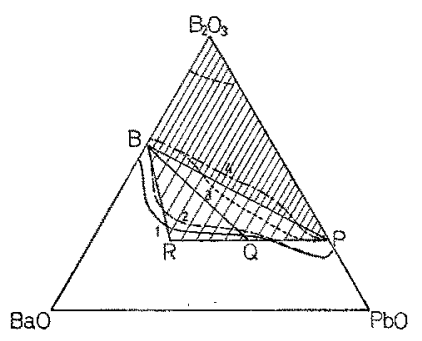

Fig. 4. Glass-formation range in $\mathrm{B}_{2} \mathrm{O}_{3}-\mathrm{BaO}-\mathrm{PbO}$ system.

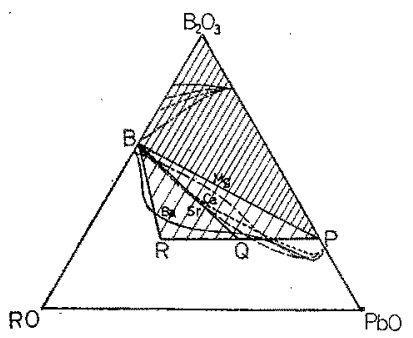

Fig. 5. Glass-formation range in $\mathrm{B}_{2} \mathrm{O}_{3}-\mathrm{RO}-\mathrm{PbO}$ system (by natural cooling).
半径の大きい゙リウ 厶架过口と日安定 でしたがって去の ガラス化の限界線も R点考通る。し方し イホン米径が小さく なるにしたがって安 定度㤬娍少し，スト

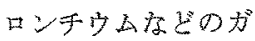
ラ、化範囲はQ $Q$ 点を 通る。さらにマグネ シ少と加アル力り 金属の場合注，B P 線にそって限界線が

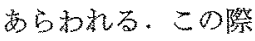
PQR 線好絧状構造 の置換限界である が， a族の場合と違 い構造と関保がある ので変動が少ない。逆にBR線住網状構造の連続性の限 界であるが，網状構造に入る b 族成分の配位構造の安定

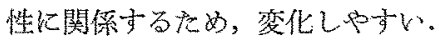

さて，泠却速度によるガラス化範围の変化が，修飾イ オンによるガラス化範囲の変化と類似することを指摘し たが，このことを一層確加なのとしているのは，图-6 に示した $\mathrm{B}_{2} \mathrm{O}_{3}-\mathrm{SrO}-\mathrm{PbO}$ 系のガラス化範国である。こ の系の室内放泠でのガラス化範囲湔述の通りでるる が，急泠すれば図ー6の実線のよ5にバリウムの系に類 似したガラス化籁囲学示す。このことは次のよらな模型

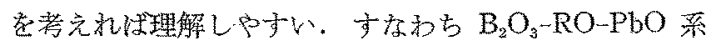
のガラス化範国住従 来のような平面的な 它で结なく, 図-7 に示すような安定度 整垂直軸とした立体 的京すのと考える。 この図で政 3 解 $\mathrm{B}_{2} \mathrm{O}_{3} \cdot \mathrm{BP}$ が多っと 安定度商人, つ いで 4 辺形 $\mathrm{B}_{2} \mathrm{O}_{3}$ 。

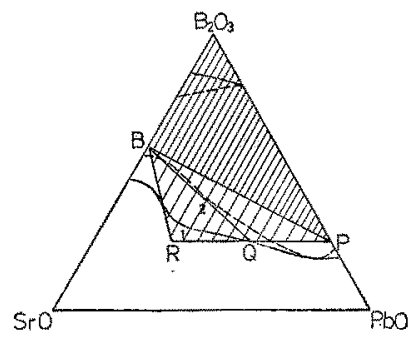

Fig. 6. Glass-formation range in $\mathrm{B}_{2} \mathrm{O}_{3}-\mathrm{SrO}-\mathrm{PbO}$ system.
$\mathrm{BQP}$ の中間段階を経て, $\mathrm{B}_{2} \mathrm{O}_{3} \cdot \mathrm{RO} \cdot \mathrm{PbO}$ 平面上の 4 辺 形 $\mathrm{B}_{2} \mathrm{O}_{3} \cdot \mathrm{BRP}$ が最低の䋈定度のガラス化範囲となる。 急冷すれば女定度の低いガラスまでガラス化し，安定軸 に対し下側のガラス化範国を示す，一力R置換した場 合，この系の最適イオン斗径に近いROの系のガラス任 安定で，それから甠ずれている系ほど不安定になる。 の場合椧却条件を一定にして执いて，安定なガラス棈 造をとりやすいROを含を系で仗，安定軸のより下側の

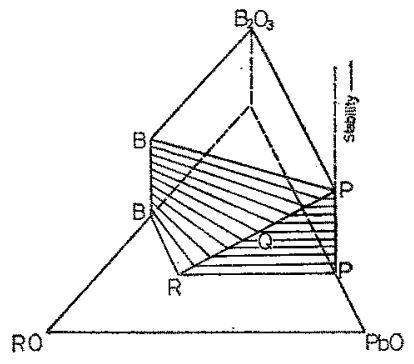

Fig. 7. Glass-formation range of ternary system including glass stability.
ガラス化範囲をとり らることになり，不 安定な組合せでは邁 に上側のガラス化箁 国し亦れなくな る.しかし後者な゙も

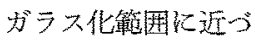
$<$.

さて以上の模型が 冷却条件を変光，急 泠していけば前者の

事䒠をよく説明する当のであれば，従来の平面的ながラ 不化範囲 (図-7 中の 4 辺形 $\mathrm{B}_{2} \mathrm{O}_{3}$. $\mathrm{BRP}$ ) 代代って, 晏 定度を含む立体的なガラス化範囲（図-7）堂考えるべき である。このこと蛙当然型 3 成分系についても言われ

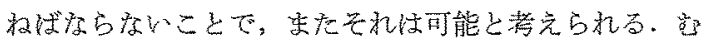
しろ iで定性的に述べたことをここでより明確にした とい充よう。す必的ち従来 $\mathrm{AD}$ または $\mathrm{B}_{2} \mathrm{O}_{3}-\mathrm{C}$ 線で示 されていたがラス化の限界が，安定度を含め沈元の 空間では面となり，しかも従来の組成面に対して垂直で はなく、ある傾きを名つといらことである。したがって 従来の限界線 ( $\mathrm{AD}, \mathrm{B}_{2} \mathrm{O}_{3}-\mathrm{C}$ など)の意味について再

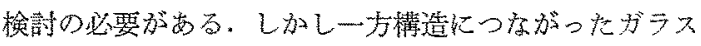
化範囲の存在ということも，いささか㤝っきりしてきた 上うに思われる。

iii. $\mathrm{B}_{2} \mathrm{O}_{3}-\mathrm{Bi}_{2} \mathrm{O}_{3}-\mathrm{PbO}$ 系 次化 b 族元素酸化物系 の代表として $\mathrm{B}_{2} \mathrm{O}_{3}-\mathrm{Bi}_{2} \mathrm{O}_{3}-\mathrm{PbO}$ 系を取上げた. ビスマ ス恬鉛に似ているが，原子価が 1 つ多く 3 価であるため 襍雑で，ガラス化範囲が広くb族系の特徴をみせてい る.この系のガラス化範围については，高鉛一゙スマス 䒺ガラス」而中ですでに取上げているが，異なる泠却速度 によるガラス化範囲 の変化を通してみる とにより(図-8 参 照)，これらのガラ ス化範国が一層よく 理解されよう。图中 の $A_{1}, A_{2}, B_{1}, B_{2} \cdots$ の諸点で, 網状構造 を形成与る構造笚位

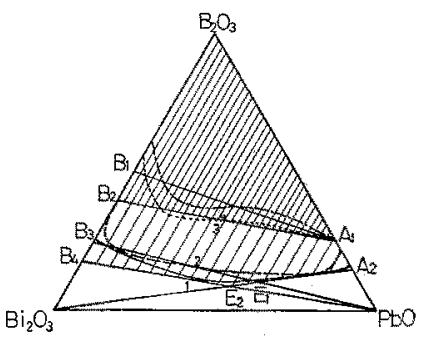

Fig. 8. Glass-formation range in $\mathrm{B}_{2} \mathrm{O}_{8}-\mathrm{Bi}_{2} \mathrm{O}_{8}-\mathrm{PbO}$ system. として考えられるものを表一少化示した。すなわちこれ

Table 1. Chain unit of network structure at $\mathrm{A}$ or $\mathrm{B}$ points (in Fig. 8 ).

\begin{tabular}{ccl} 
Point & $\mathrm{B}_{2} \mathrm{O}_{3}$ mol \% & \multicolumn{1}{c}{ Chain unit } \\
$\mathrm{A}_{1}$ & 25.0 & $\mathrm{~B}-\mathrm{Pb}-\mathrm{B}$ \\
$\mathrm{A}_{2}$ & 14.3 & $\mathrm{~B}-\mathrm{Pb}-\mathrm{Pb}-\mathrm{B}$ \\
$\mathrm{B}_{1}$ & 50.0 & $\mathrm{~B}-\mathrm{Bi}-\mathrm{B}$ (all chains) \\
$\mathrm{B}_{2}$ & 40.0 & $\mathrm{~B}-\mathrm{Bi}-\mathrm{B}$ \\
$\mathrm{B}_{3}$ & 25.0 & $\mathrm{~B}-\mathrm{Bi}-\mathrm{Bi}-\mathrm{B}$ (all chains) \\
$\mathrm{B}_{4}$ & 18.2 & $\mathrm{~B}-\mathrm{Bi}-\mathrm{Bi}-\mathrm{B}$
\end{tabular}


25 今岡稆傜方

ら諸点でBとBの間をつないでいるる族イオンの数が違 っている。この数はもらろん少ない方がガラスとして安 定で, これは当然網状構造の置換限界でもある。 $\mathrm{B}_{2} \mathrm{O}$ $\mathrm{RO}-\mathrm{PbO}$ 系ではこのような置換限界注 $\mathrm{Pb} / \mathrm{B}=1$ kほ ぼ限定されていたが、ビスマスは前述のよらに原子価が 多く複雑で， $\mathrm{B}_{2} \mathrm{O}_{3}-\mathrm{Bi}_{2} \mathrm{O}_{3}-\mathrm{PbO}$ 系などでは急冷してい った場合に， $\mathrm{Bi} / \mathrm{B}=2$ あるいはそれ以上にまで及ぶこと がある。な挍 $\mathrm{E}_{1}, \mathrm{E}_{2}$ などの点があらわれるのは，一般 にb族イオンが 2 種以上混在するようになると，Bと B との間をつなぐb族イオンの数はさらに増す，とみられ る加らである。

$\mathrm{b}$ 族元素酸化物系 で站 $\mathrm{b}$ 族イオン/ガラス形成イオン の比分，a-b 族元素酸化物䒺の上らに限定さ机尔いた め，ガラス化範囲全体が網状構造の置換限界だけに支配 されている，かつその置換率性冷却条件に支配される， そいらきわわて解りよい結果となった。一定の置換率老

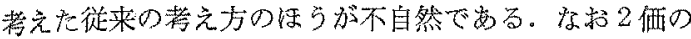
b族イオン $\mathrm{Zn}, \mathrm{Cd}, \mathrm{Pb}$ を一つにまとめて議論すること は困難であるが，いゔれる大同小異で方ることは確かで 亦る。

\section{B。例外的 3 成分系}

i. $\mathrm{B}_{2} \mathbf{O}_{3}-\mathbf{M g O}-\mathbf{B a O}$ 系さて, 以上 3 つの例を取 上げて議諭し，それによって多くの3成分系を推論しよ らといらわけであるが，その中には従来例外として取扱 われ，そのガラス化範囲の意味も十分理解されてい斿か っをものもあるのでここにその幾つが取上げてこれ までの議論の補足とし，従来例外的とみられていたもの 为冷却速度の変化を含めた 3 次元的ガラス化範囲の中 でどのような位置にあるものかを明かにしてみたい。

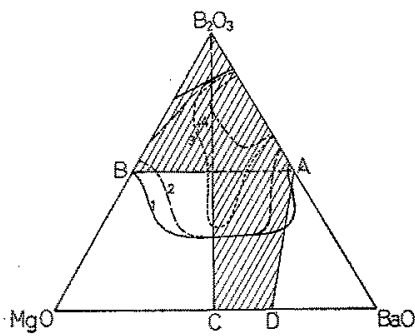

Fig. 9. Glass-formation range in $\mathrm{B}_{2} \mathrm{O}_{8}-\mathrm{MgO}-\mathrm{BaO}$ system.

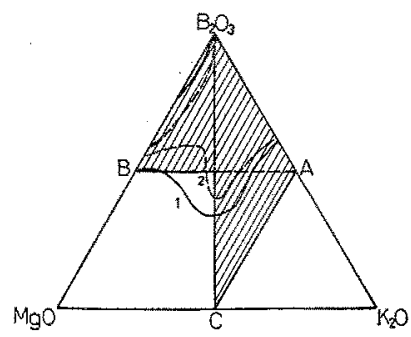

Fig. 10. Glass-formation range in $\mathrm{B}_{2} \mathrm{O}_{3}-\mathrm{MgO}-\mathrm{K}_{2} \mathrm{O}$ system.
そこで柰す $\mathrm{B}_{2} \mathrm{O}_{3}$ $\mathrm{MgO}-\mathrm{BaO}$ 系要取上 げるわけであるが， この系では Mg が 4 配位の絧状構造成 分と, 2 価の修飾成 分の雨方の役割が可 能でるる考党ら れ，図-9の中の斜 線部分で示されたガ ラス化範国怔期待さ れる。しかし徒来の ガラス化範囲の測定 結舁(図-9中の破 線) では，斜氍部分 の左下に大きく惊み 出したガラス化領域 があり、これまで説。 明七にく、例外的存

在でめった。そこで椧却速度学変えてこの系のガラス化

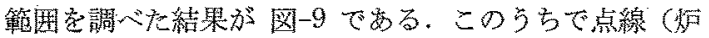
内放冷）で示されたガラス化範国は，図-10 に示された $\mathrm{B}_{2} \mathrm{O}_{3}-\mathrm{MgO}-\mathrm{K}_{2} \mathrm{O}$ 系の破線（堂内放冷）と占く似て招 り，主として網状構造成分としての $\mathrm{Mg}$ の゙ラス化範 国といらことが出来る.したがって $\mathrm{B}_{2} \mathrm{O}_{3}-\mathrm{MgO}-\mathrm{BaO}$ 系に抢ける，斜線部分加らはみ出した左下のガラス化部 分は； $\mathrm{B}_{2} \mathrm{O}_{3}-\mathrm{C}$ 線の右側の斜線部分のそれにくらべて， 安定度の低いものたしいえる。一般に急泠していった場

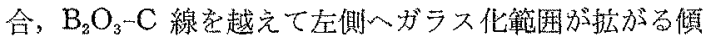
向はあるが，この場合もそれであるとしてよいかどうか 妨别として，こ5した安定度の低い部分定除いて考えれ

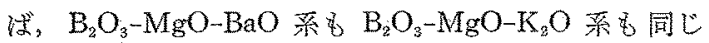
である、そればかりか後者に叔いて急冷してゆけば, バリウム系と同様斜線部分の左下にガラス化範囲忧拡

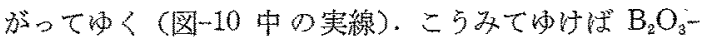
$\mathrm{MgO}-\mathrm{BaO}$ 系の例外的位置ははっきりして来た。

\section{ii。 $\mathrm{B}_{2} \mathrm{O}_{3}-\mathrm{TiO}_{2}-\mathrm{BaO}$ 系 次にチタン系であるが，} これは磁酸塩系と珪酸塩やゲルマネート系でガラス化範

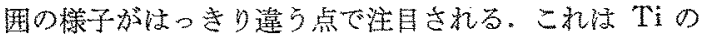

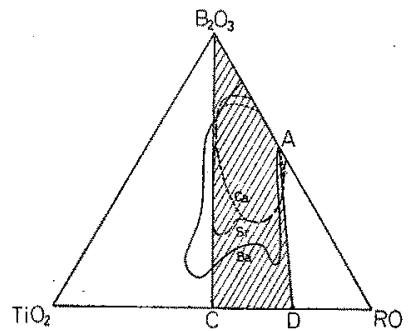

Fig. 11. Glass-formation range in $\mathrm{B}_{2} \mathrm{O}_{3}-\mathrm{TiO}_{2}-\mathrm{RO}$ system.

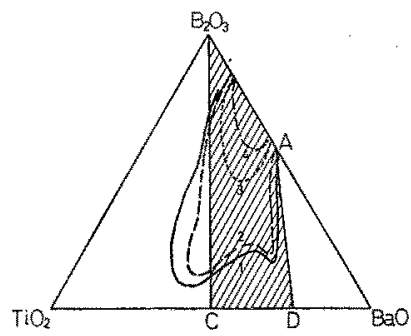

Fig. 12. Glass formation range in $\mathrm{B}_{2} \mathrm{O}_{3}-\mathrm{TiO}_{2}-\mathrm{BaO}$ system.

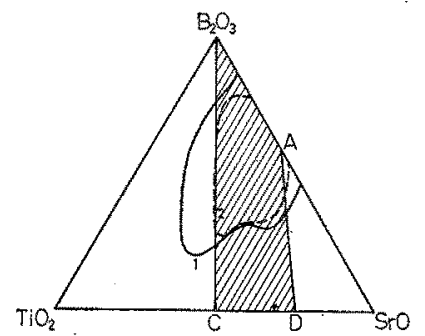

Fig. 13. Glass-formation range in $\mathrm{B}_{2} \mathrm{O}_{8}-\mathrm{TiO}_{2}-\mathrm{SrO}$ system.
配位数に関係する のと想像される。 $\mathrm{B}_{2} \mathrm{O}_{3}-\mathrm{TiO}_{2}-\mathrm{RO}$ 丞 の予測されるガラス 化範国怔図-11の 斜線部分『示され る。极放の場合 $\mathrm{Ti}$ の配位数は 6 と考え ている。図-11 加 明ら加なよに，こ のららバリウム系の ガラス化範囲の多 恃特似店く $\mathrm{B}_{2} \mathrm{O}_{3}-\mathrm{C}$ 線学越えてガラス化 する. $\mathrm{B}_{2} \mathrm{O}_{3}-\mathrm{TiO}_{2}-$ $\mathrm{BaO}$ 系のガラス化 範国注図-12 亿示 した。 これから明ら 加な上らに，冷却速 度が遅くなると务 又化範国は急速にら ぢまり，もちろん $\mathrm{B}_{2} \mathrm{O}_{3}-\mathrm{C}$ 線加方左側 ヘのは名山しはなく なる。东た逆に图一 13 亿示した $\mathrm{B}_{2} \mathrm{O}_{3}$ $\mathrm{TiO}_{2}-\mathrm{SrO}$ 系で被, 従来のガラス化範国 
(破線)にはは出し注多られないが，急洽（実線）し たときはバリウ入系に近いガラス化範围を示す。したが って $\mathrm{B}_{2} \mathrm{O}_{3}$-C 線の左側のガラス化部分は, 安定度の低、 状態と考光られる。またこの系柱 B型 3 成分系に属ずる ものであり，図-11 のROの修飾成分を直撸した場合の ガラス化範国の変化が, 図-12 の泠却速度を変えていっ た場合の変化とよく似て衫り，A. ii. の $\mathrm{B}_{2} \mathrm{O}_{3}-\mathrm{RO} \mathrm{PbO}$ 系でいえたことが，ここです当然い党ることを示してい る。

iii. $\mathrm{B}_{2} \mathrm{O}_{3}-\mathrm{WO}_{3}-\mathrm{R}_{2} \mathrm{O}$ 系 このタングステンを含む 系牥，図-14 にみるように不混領域为存在するためガラ

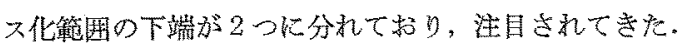
この不混領域の存在について祝来次のように考完て来 た。すなわちタングステン酸にはアルカリの量により $\mathrm{WO}_{3}, \mathrm{R}_{2} \mathrm{WO}_{4}, \mathrm{R}_{8} \mathrm{WO}_{6}$ のつがある. 第 1 と第 3 法 6

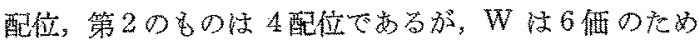
4 配位のタングステン酸出連続な網目構造を形成しえな い，そのためここに不混領域が存在するというわけであ

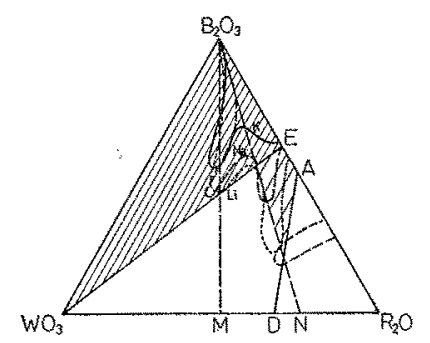

Fig. 14. Glass-formation range in $\mathrm{B}_{2} \mathrm{O}_{8}-\mathrm{WO}_{3}-\mathrm{R}_{2} \mathrm{O}$ systems.

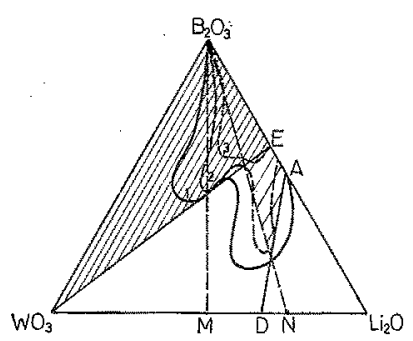

Fig. 15. Glass-formation range in $\mathrm{B}_{2} \mathrm{O}_{3}-\mathrm{WO}_{3}-\mathrm{Li}_{2} \mathrm{O}$ system.

の変化によく似ている。すなわち右側の ガラス化部分が変化しやすく, 泠却速度 が遅くなると（監換の場合はイオン半径 が大きくなると）消えていくのに対し， 左側のガラス化範囲は急激な変化を起さ ない、したがって後者の方が安定度の大 きいガラスとみるべきであるう。ところ で急冷していくことにより $\mathrm{M} \cdot \mathrm{B}_{2} \mathrm{O}_{3} \cdot \mathrm{N}$ 内の不混領域が消えないだるらか，とい うのも興味ある点で亦った・。ちろん完 全に消えはしなかったが，この領域でも
ガラス化範囲は拡がっているので，消える方向にあ ることはうかがえた，以上の結果加ら教えると， $\mathrm{WO}_{3}$ と $\mathrm{R}_{6} \mathrm{WO}_{6}$ の間にガラス化不可能な 4 配位構造分存在 するという考光方より， $\mathrm{B}_{2} \mathrm{O}_{3}$ や $\mathrm{SiO}_{2}$ と2 価金属酸化 物の系にみられる不混領域と同様, 修飾イオンを取らな W $\mathrm{WO}_{3}$ と修飾イオンを十分取った $\mathrm{R}_{x} \mathrm{WO}_{6}$ との間の 不混領域，といら考え方のほらがよさそらにみえる。 ちろんこの場合流 $\mathrm{B}_{2} \mathrm{O}_{3}$ ない $\mathrm{R}_{y} \mathrm{BO}_{3}$ 注存在してい る.また図-14,15で $\mathrm{E} \cdot \mathrm{WO}_{3}$ 線より上側では, 組成 上から修飾イオンを取らない $\mathrm{WO}_{3}$ の存在が可能で㐌 る.

iv。 $\mathbf{B}_{2} \mathbf{O}_{3}-\mathbf{B i}_{2} \mathbf{O}_{3}-\mathbf{R}_{2} \mathbf{O}$ 系 これらの系のうちカりウ ムの系は前項同様, 不混領域をはさんで2つのガラス化 部分にわかれて括り，注目されるが，前項のタングステ ン系と注なり，残りのナトリウム、リチウム系にはを

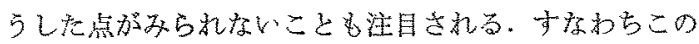
系のガラス化範国を图-16 に示した。この場合も急冷 していったら不混領域が消えてゆくのか，といった点に 舆味もるが，さらにこの3つのかなり違った古ラス化 範用をむつ系が，これまでと同様互に同一の 3 次元的力゙ ラス化範囲をもち，アルカリイオンの置換による変化 を, 冷却速度を変えることによって再現出来るか，とい った点に関心がよせられる。その結果注図-17〜19 に示 した。従来の例より 3 者のガラス化範围の間の差が大き いだけに，十分それを再現するところをで注いかない が，カリウム系では急冷することにより不混領域が消充 ていく方向がらかがわ称，一方ナトリウム，リチウム系 では徐冷することにより不混領域が現われ搪がって，い く傾向がみられる。したがってこの場合にもこれまで同 変化はアルカリを置 換した場合（図-14）

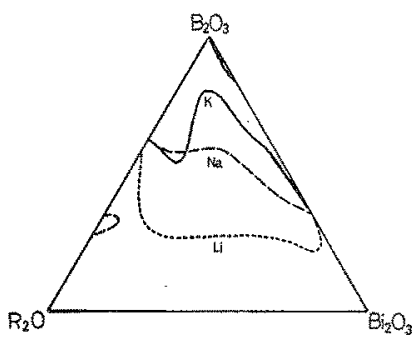

Fig. 16. Glass-formation range in $\mathrm{B}_{2} \mathrm{O}_{3}-\mathrm{R}_{2} \mathrm{O}-\mathrm{Bi}_{2} \mathrm{O}_{3}$ system.

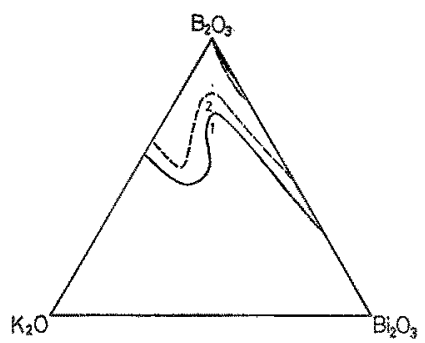

Fig. 17. Glass-formation range in $\mathrm{B}_{2} \mathrm{O}_{3}-\mathrm{K}_{2} \mathrm{O}-\mathrm{Bi}_{2} \mathrm{O}_{3}$ system.

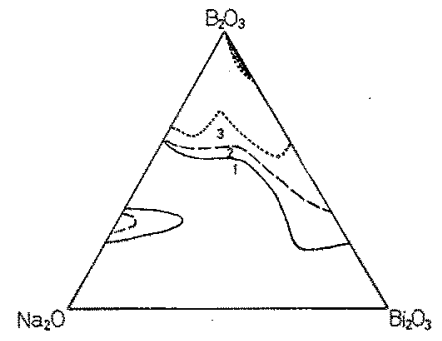

Fig. 18. Glass-formation range in $\mathrm{B}_{2} \mathrm{O}_{3}-\mathrm{Na}_{2} \mathrm{O}-\mathrm{Bi}_{2} \mathrm{O}_{3}$ system.

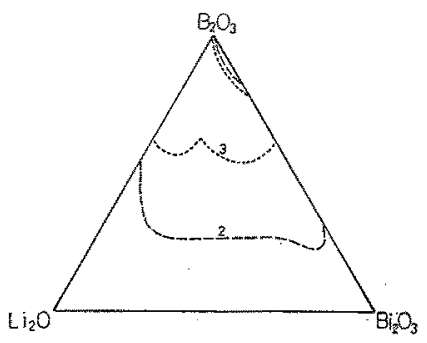

Fig. 19. Glass-formation range in $\mathrm{B}_{2} \mathrm{O}_{3}-\mathrm{Li}_{2} \mathrm{O}-\mathrm{Bi}_{2} \mathrm{O}_{3}$ system. 
様, $\mathrm{B}_{2} \mathrm{O}_{3}-\mathrm{R}_{2} \mathrm{O}-\mathrm{Bi}_{2} \mathrm{O}_{3}$ 系として 1 つのガラス化範囲(安 定度を含为た）をもつことが明らかになった。ただ $\mathrm{B}_{2} \mathrm{O}_{3}-\mathrm{K}_{2} \mathrm{O}-\mathrm{Bi}_{2} \mathrm{O}_{3}$ 系の左側のガラス化範囲は, 従来カリ ウム定修飾イオンとした Bi の 6 配位化によるものと考 えていたが，これが正しいとした場合，イオン半径だけ でなくアルカリイオンの塩基度も関係することが想像さ れ，それが置換によるガラス化範囲の差を大きくしてい るのではないかと思われる。

\section{IV.ガラス化範囲と状態図との関係}

次にガラス化範囲と状態図との関係を調べてみた。 以 上のガラス化範囲と冷却速度の関係から明らかなよう 飞，ガラス化の限界は一定ではなく安定度の函数であ る。その際ガラス化範囲の変化は状態図の影響下にある ものか，あるい性全く無関係なものかなど興味ある点で 苏る。

i。 $\mathbf{B}_{2} \mathbf{O}_{3}-\mathbf{R}_{2} \mathbf{O}$ 系 第 1 亿簡単な 2 成分系について Glass-formation Range*

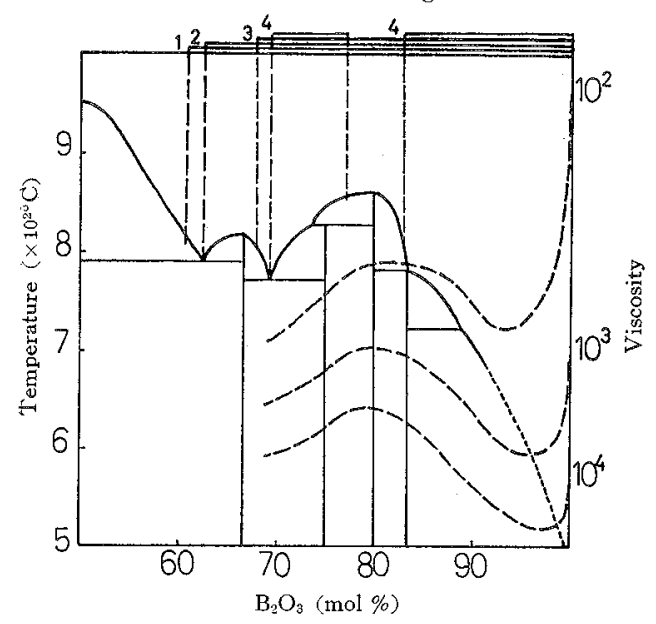

Fig. 20. Phase-diagram, viscosity and Glassformation range of $\mathrm{B}_{2} \mathrm{O}_{3}-\mathrm{K}_{2} \mathrm{O}$ system.

* Numbers mean cooling rate (cf. Fig. 2). Glass-formation Range

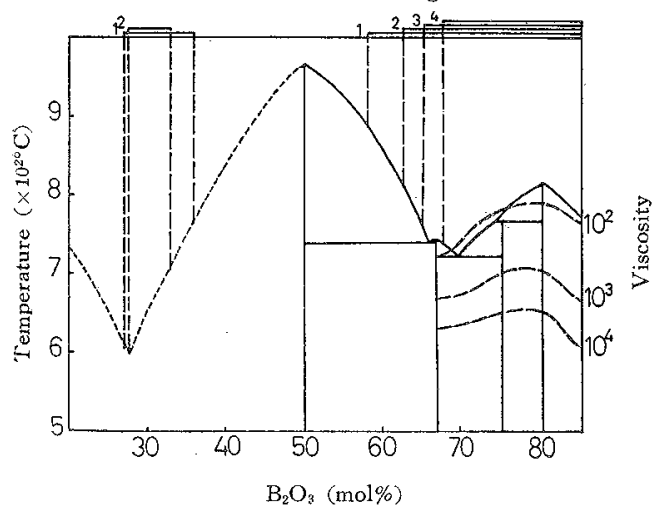

Fig. 21. Phase-diagram, viscosity and Glassformation range of $\mathrm{B}_{2} \mathrm{O}_{3}-\mathrm{Na}_{2} \mathrm{O}$ system.

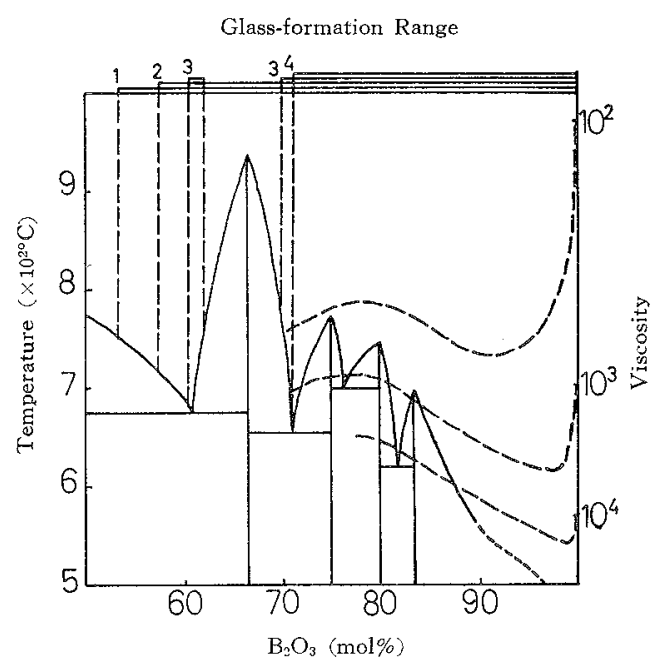

Fig. 22. Phase-diagram, viscosity and glassformation range of $\mathrm{B}_{2} \mathrm{O}_{3}-\mathrm{Li}_{2} \mathrm{O}$ system.

みていこう。ここでは網状構造の連続限界が現われるわ けである。それらの代表としてここに $\mathrm{B}_{2} \mathrm{O}_{3}-\mathrm{R}_{2} \mathrm{O}$ 系を 選んだが，どれでも結果は大同小異である。図-20〜22 にカリウム,ナトリウム, リチウムの各系を示した。な 抢粘度も解った範囲で入れて赫いたが，アルカリの多、 側では実測值がえられなかった。この領域では結晶しや すく測定しにくい，ガラス化が融点附近の液体の粘度に 支配されるとの考えに立つと，アルカリの多い側での測 定值を欠いているが，一般に組成に対して余り急激な粘 度変化はないとして，近似的に粘度一定と仮定すれば， 液相線の山の部分はガラス化しにくく，逆にその谷の部 分がガラス化しやすいことになる。確かにこうした傾向 は以上の状態図の中で容易に発見される。例えば $\mathrm{B}_{2} \mathrm{O}_{3}-$ $\mathrm{K}_{2} \mathrm{O}$ 系 (図-20), $\mathrm{B}_{2} \mathrm{O}_{3}-\mathrm{Li}_{2} \mathrm{O}$ 系 (図-22) で, 液相線の 山の部分には徐冷していくと結晶化部分が現われる ( $\mathrm{K}_{2} \mathrm{O} 20 \%$ 附近, $\mathrm{Li}_{2} \mathrm{O} 33 \%$ 附近). また逆に $\mathrm{B}_{2} \mathrm{O}_{3}$ $\mathrm{Na}_{2} \mathrm{O}$ 系 (図-21) では $\mathrm{Na}_{2} \mathrm{O} 7.0 \mathrm{~mol} \%$ 附近の谷に, 放冷以上の冷却速度の場合小ガラス化範囲が現われる。 したがってガラス化範囲は状態図の影響を受けていると いえよう。しかし $\mathrm{B}_{2} \mathrm{O}_{3}-\mathrm{R}_{2} \mathrm{O}$ 系のガラス化範囲がほぼ 一定していることは, 状態図だけからは出てこない。む しろ従来考えて来たような網状構造の連続限界が $\mathrm{R}_{2} \mathrm{O}$ $50 \mathrm{~mol} \%$ のところにあって，それが更に2 次的に状態 図の影響をうけている，と考光る方が妥当である。例充 ば $\mathrm{B}_{2} \mathrm{O}_{3}-\mathrm{Li}_{2} \mathrm{O}$ 系で $2 \mathrm{~B}_{2} \mathrm{O}_{3} \cdot \mathrm{Li}_{2} \mathrm{O}$ の山の影響の現われ るのは, 炉内放冷以下の遅い冷却速度の場合であって, それより急冷された場合に注 $60 \mathrm{~mol} \% \mathrm{~B}_{2} \mathrm{O}_{3}$ まで結晶 化部分は見出されない。しかし単に状態図の液相線の山 谷がガラス化範囲を決定するのであれば， $50 \mathrm{~mol} \%$ の $\mathrm{B}_{2} \mathrm{O}_{3} \cdot \mathrm{Li}_{2} \mathrm{O}$ の山よりも高い $2 \mathrm{~B}_{2} \mathrm{O}_{3} \cdot \mathrm{Li}_{2} \mathrm{O}$ の山がガラ ス化して, $\mathrm{B}_{2} \mathrm{O}_{3} \cdot \mathrm{Li}_{2} \mathrm{O}$ の山越えてガラス化出来ない 
という等はない，したがってここではガラスの網状構造 の概念が優先する，も舌んこの結果は，当然予測され たところで意外とするに足りない，結晶化は融点附近の 粘度のみによって支配されるるのではなく, 熔融状態と 結晶状態との差の函数でもある。ただこれまでのガラス 化範囲の問題の取扱い方の中には, 結晶状態のことは何 も考慮に入れて来なかった。いわば熔融状態の構造だけ を問題にしてきた。しかし安定な網状構造をもつ範囲に 晾いては，それで十分であることが明らかになった。と くにそのことは，実際問題としてガラス化範囲を考えて いく上に，大事な点であると思う。

ii 3 成分系 次にB型 3 成分系につけて実例を求

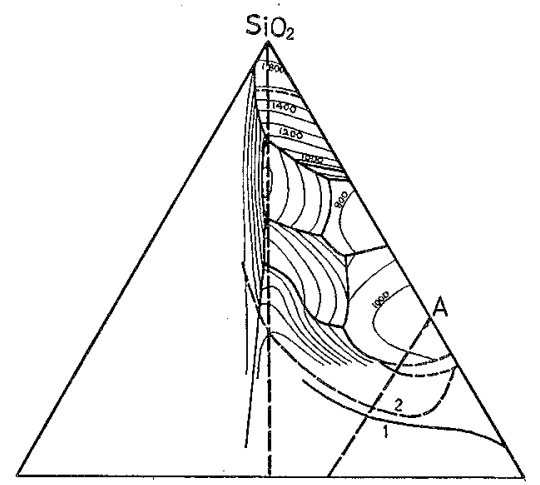

Fig. 23. Phase-diagram ${ }^{7}$ and glass-formation of $\mathrm{SiO}_{2}-\mathrm{Al}_{2} \mathrm{O}_{3}-\mathrm{Na}_{2} \mathrm{O}$ system.

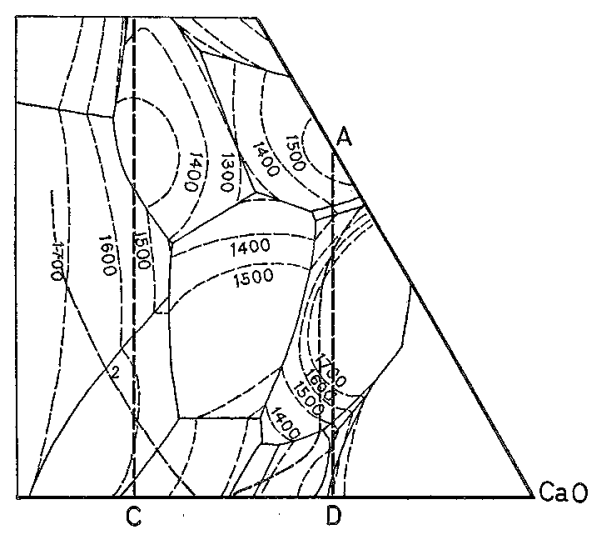

Fig. 24. Phase-diagram ${ }^{8}$ and glass-formation range of $\mathrm{SiO}_{2}-\mathrm{Al}_{2} \mathrm{O}_{3}-\mathrm{CaO}$ system.
めたが，状態図のデータがそしく適当なものは少なかっ た.ここに $\mathrm{SiO}_{2}-\mathrm{Al}_{2} \mathrm{O}_{3}-\mathrm{Na}_{2} \mathrm{O}$ 系招よび $\mathrm{SiO}_{2}-\mathrm{Al}_{2} \mathrm{O}_{3}$ -

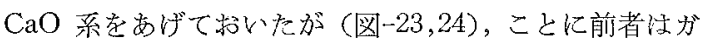
ラス化範围の限界線上の状態が十分明らかにされて抢ら ず，余り適当とはいてえない，後者はその点では十分で女 るが，ガラス化範囲は室内放泠の結果のみである、いず れにしても結論は前項と同じである.このことはさらに 多くの 3 成分系の状態図が明らかになれば，いっそう法 っきりしてくることと思う。

$$
\text { V むすび }
$$

以上ガラス化範囲の実験結果を再岭味するため, 従来 の室内放泠のほかに 3 つの泠却条件を加え, 冷却速度に よるガラス化範囲の変化を調べを，その結果次のような ことが明らかになった。すなわち，

1 つの系で，その䒺の修飾成分を同族イオンで置換し ていった場合のガラス化範囲の変化と，成分を変えずに 冷却速度を変えた場合のガラス化範囲の変化とは，似て いる.

そのことから次のようなことが結論される。すなお ち，1つの冷却条件からえられたガラス化範囲の結果 は，必ずしも絶対的意味をもたない，しかし1つの系に は 図-7 に示すような, 安定度を含めた 3 次元的な固有 のガラス化範囲が存在し，その中で従来のある修飾成 分, ある玲却条件での結果住, 相当する安定度で切った 1 つの断面である, と考栄られる。

なお，状態図とガラス化範囲の関係も調べたが，ガラ スの安定領域は従来のガラス化範囲の考え方で説明出来 る。しかし不安定領域では液相液の影響を受河, その山 の部分ではガラス化しにくくて，谷の部分にガラス化範. 囲を見出しやすい，といえる。

\section{文献}

1）今岡稔, 案協, 67, 364 (1959).

2）今岡稔，筧協，69, 282 (1961).

3) 今阔念, 山㱦敏子, 嚜協, 71,215 (1963)。

4) 今岡稔, 山崎敏子. 空拹, 72,182 (1964).

5) H. Rawson, IV Congrés International du Verre, 62 (1956).

6) 今岡稔, 工化, 64, 871 (1961)。

7) Phase Diagrams for Ceramists. Fig. 501 (1964).

8）同上, Fig。 630

$(7 / 12 / 65$ 受付 $)$

\section{Errata. (正誤表) Vol. 74 [1] 1966}

p. 21 th from bottom in Table $2: 77 \mathrm{CaO} \cdot 2.8 \mathrm{Al}_{2} \mathrm{O}_{3}$. $\mathrm{Fe}_{2} \mathrm{O}_{3}$ should be $7.7 \mathrm{CaO} \cdot 2.8 \mathrm{Al}_{2} \mathrm{O}_{8} \cdot \mathrm{Fe}_{2} \mathrm{O}_{3}$

p. 22 2nd from top : $p=0.33\left(=0.4 \mathrm{CaO} \cdot 2.2 \mathrm{Al}_{2} \mathrm{O}_{8}\right.$. should be $p=0.33\left(=6.4 \mathrm{CaO} \cdot 2.2 \mathrm{Al}_{2} \mathrm{O}_{3}\right.$.

rightside of Fig.2. : ..Percentage of hydration(\%) should be----Percentage of hydration(\%). p. 23 3th from top under Fig. 6. (electron micrograph) : and Hexagonal plate like crystal should be omitt.

p. 24 Electron micrograph of Fig. 8. and Fig. 10. should be exchange each other.

p. 25 2nd from bottom in title sentence of Fig. 11. : conponent should be component.

3rd from top under Fig. 14. : unit: A should be unit : $\AA$. 